\title{
THE TYPEWRITER CENTURY
}

A Cultural History of Writing Practices 



\section{The Typewriter Century}

\section{A Cultural History of Writing Practices}

MARTYN LYONS

UNIVERSITY OF TORONTO PRESS

Toronto Buffalo London 
(C) University of Toronto Press 2021

Toronto Buffalo London

utorontopress.com

Printed in the U.S.A.

ISBN 978-1-4875-0824-1 (cloth)

ISBN 978-1-4875-2573-6 (paper)

ISBN 978-1-4875-3783-8 (EPUB)

ISBN 978-1-4875-3782-1 (PDF)

Studies in Book and Print Culture

\section{Library and Archives Canada Cataloguing in Publication}

Title: The typewriter century : a cultural history of writing practices / Martyn Lyons.

Names: Lyons, Martyn, author.

Series: Studies in book and print culture.

Description: Series statement: Studies in book and print culture | Includes bibliographical references and index.

Identifiers: Canadiana (print) 20200304984 | Canadiana (ebook) 20200305018 | ISBN 9781487508241 (hardcover) |

ISBN 9781487525736 (softcover) | ISBN 9781487537838 (EPUB) | ISBN 9781487537821 (PDF)

Subjects: LCSH: Typewriters - History. | LCSH: Typewriters Social aspects. | LCSH: Typewriting - History.

Classification: LCC Z49.A1 L96 2020 | DDC 652.3 - dc23

Chapter opening illustration: AVA Bitter/Shutterstock.com

University of Toronto Press acknowledges the financial assistance to its publishing program of the Canada Council for the Arts and the Ontario Arts Council, an agency of the Government of Ontario.

Canada Council for the Arts
Conseil des Arts du Canada

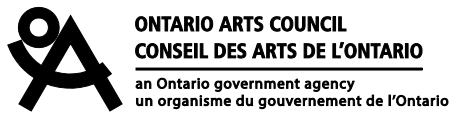

